American J. of Engineering and Applied Sciences 3 (4): 643-649, 2010

ISSN 1941-7020

(C) 2010 Science Publications

\title{
Optimization of Mix Proportion of High Performance Mortar for Structural Applications
}

\author{
Cheah Chee Ban and Mahyuddin Ramli \\ Sustainable Housing Research Unit, School of Housing, Building and Planning, \\ University Sains Malaysia, 11800 Penang, Malaysia
}

\begin{abstract}
Problem statement: Mortar mix is a major construction material in fabrication of ferrocement structural elements. However, there have been scarce amount of technical data available on suitable mix proportion to achieve structural grade mortar with specific strength requirement and adequate level of workability for proper placement into construction formwork. Moreover, current practice in ferrocement construction work which uses mortar mix with cement: sand ratio ranging between 1:1.5 to 1:2 incurs high requirement of cement yet producing mix with suboptimum level of compressive strength. Approach: An experimental investigation was carried out to evaluate workability and compressive strength properties of structural grade mortar mixes with various cement: sand ratios ranging from 1:2.0-1:2.75 and varying water/binder ratio between 0.35 and 0.50 . Throughout the laboratory investigation, a total of 28 batches of mortar mixes with various mix proportion were designed, cast and tested in accordance to relevant standards of practice prescribed by British Standard Institute (BSI) and American Society of Testing Material (ASTM). Results: At the end of the laboratory investigation program, high performance mortar mix with compressive strength exceeding $55 \mathrm{MPa}$ and slump level within $50-90 \mathrm{~mm}$ which is suitable for heavy duty ferrocement construction work was successfully developed. Moreover, data on mix proportion for several other grades of mortar mixes ranging from grade 35 to grade 55 were also derived. Conclusion: It was found that optimum cement: Sand ratio of structural mortar is 1:2.25. With the use of this cement: Sand ratio in the production of structural grade mortar mix in fabrication of ferrocement structural elements, consumption of cement binder will be economized hence resulting in potential savings in term of material and production cost of mortar mix in the construction industry. Besides, it was also observed that strengths of mortar mixes do not vary linearly with cement content of the mix.
\end{abstract}

Key words: High performance mortar, mix proportioning, medium workability

\section{INTRODUCTION}

Since the introduction of ferrocement system by Joseph Louis Lambot in the year 1852, mortar mix has been widely used as major constituent material of the versatile system and typically reinforced with flexible woven wire mesh or welded wire mesh. Ferrocement had been widely used as construction material for boats and yards for almost a century after its introduction. Conventional ferrocement consists of two main components which are reinforcing mesh and mortar paste matrix. Over the years, mortar mix typically used for ferrocement application has cement-sand proportion of 1 part cement with $1.5-2$ parts of sand with water/cement ratio to be maintained as low as possible to give the mortar mix a consistent quality and workability. Typically, water/cement ratio of 0.4 is desirable in most ferrocement application (Nedwell and
Swamy, 1994). However, the aforementioned mix proportion of mortar mix is not optimized in term of their mechanical strength and material consumption. This is mainly because conventional mortar mix with cement: Sand ratio of 1:1.5 and water/cement ratio of 0.4 for instance may result in high cement content of approximately $802 \mathrm{~kg}$ of cement for every cubic meters of mix produced. The laboratory investigation program of this study is designed to determine optimum proportion of mortar mix to achieve best strength performance with acceptable level of workability.

\section{MATERIALS AND METHODS}

Materials: ASTM Type I cement with specific gravity of 3.15 was used as binder throughout the laboratory investigation program. Chemical properties of the cement is presented in Table 1 .

Corresponding Author:Cheah Chee Ban, Sustainable Housing Research Unit, School of Housing, Building and Planning, University Sains Malaysia, 11800 Penang, Malaysia Tel: +6016-4846502 
Am. J. Engg. \& Applied Sci., 3 (4): 643-649, 2010

Fine aggregate used were locally sourced natural river sand with specific gravity of 2.83 and passing sieve with opening size of $5 \mathrm{~mm}$. Fine aggregates were dried to saturated surface dry condition prior to use as constituent material in mortar mixes. Fine aggregates were graded in accordance to BS812-102: 1990 (British Standards Institution, 1990) and grading of fine aggregates used complies with overall grading limits of BS 882:1992 (British Standards Institution, 1992) as shown in Fig. 1. Type F super plasticizer of sulfonated melamine formaldehyde condensates category was used in certain mix to maintain desired level of workability. Water from local water supply network was used as mixing water for all mixes.

Mix proportions and mixing methods: Material proportions and quantities of mortar mixes cast and tested in the study are shown in Table 2. In the first part of the laboratory investigation, a total of 20 batches of mortar mix with cement: Sand ratio of 1: 2.0, 1:2.25, $1: 2.5$ and $1: 2.75$ each with water binder ratio varied from 0.40-0.5 with stepped increment of 0.025 was fabricated. For the second part of the laboratory investigation, additional 8 batches of mortar mix (Batch 21-28) with cement: Sand ratio of 1:2.25 and 1:2.5 with varying water/binder ratio of $0.35-0.425$ at stepped increment of 0.025 were fabricated. Super plasticizer was used at dosage to maintain slump of mix within the range of 50-90mm, prescribed in BS EN 206-1:2000 (British Standards Institution, 2000) as medium workability concrete (S2 Slump Class). BS5328-1: 1997 (British Standards Institution, 1997) specify S2
Workability class with nominal slump of $75 \mathrm{~mm}$ as suitable for application in fabrication of normal reinforced concrete beam, slab and wall.

Table 1: Chemical composition of type I OPC

\begin{tabular}{lc}
\hline Constituent & Ordinary portland cement (wt. \%) \\
\hline Lime $(\mathrm{CaO})$ & 64.64 \\
Silica $\left(\mathrm{SiO}_{2}\right)$ & 21.28 \\
Alumina $\left(\mathrm{Al}_{2} \mathrm{O}_{3}\right)$ & 5.60 \\
Iron oxide $\left(\mathrm{Fe}_{2} \mathrm{O}_{3}\right)$ & 3.36 \\
Magnesia $(\mathrm{MgO})$ & 2.06 \\
Sulphur trioxide $\left(\mathrm{SO}_{3}\right)$ & 2.14 \\
$\mathrm{~N}_{2} \mathrm{O}$ & 0.05 \\
Loss of ignition & 0.64 \\
Lime saturation factor & 0.92 \\
$\mathrm{C}_{3} \mathrm{~S}$ & 52.82 \\
$\mathrm{C}_{2} \mathrm{~S}$ & 21.45 \\
$\mathrm{C}_{3} \mathrm{~A}$ & 9.16 \\
$\mathrm{C}_{4} \mathrm{AF}$ & 10.20 \\
\hline
\end{tabular}

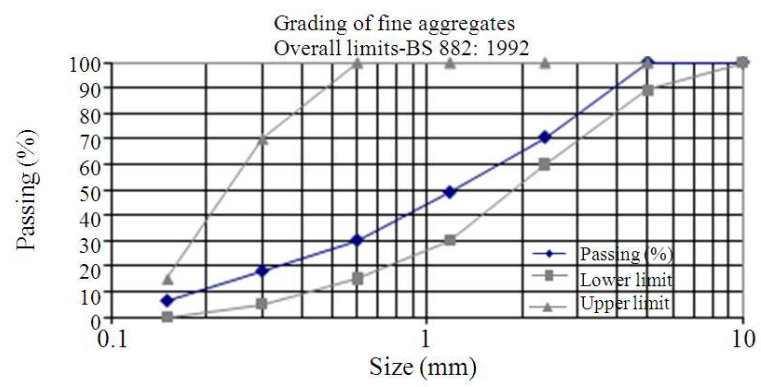

Fig. 1: Grading of fine aggregates used in the study

Table 2: Mortar mix proportions and quantities of constituent materials

\begin{tabular}{|c|c|c|c|c|c|c|}
\hline Cement: Sand ratio & Super plasticizer (\%) & Water/binder ratio & Cement $\left(\mathrm{kg} \mathrm{m}^{-3}\right)$ & Fine aggregates $\left(\mathrm{kg} \mathrm{m}^{-3}\right)$ & Water $\left(\mathrm{kg} \mathrm{m}^{-3}\right)$ & Super plasticizer $\left(\mathrm{kg} \mathrm{m}^{-3}\right)$ \\
\hline \multirow[t]{5}{*}{$1: 2.00$} & 0.000 & 0.400 & 702.000 & 1404 & 281.000 & 0.00 \\
\hline & 0.000 & 0.425 & 690.000 & 1380 & 293.000 & 0.00 \\
\hline & 0.000 & 0.450 & 678.000 & 1357 & 305.000 & 0.00 \\
\hline & 0.000 & 0.475 & 667.000 & 1334 & 317.000 & 0.00 \\
\hline & 0.000 & 0.500 & 656.000 & 1312 & 328.000 & 0.00 \\
\hline \multirow[t]{5}{*}{$1: 2.25$} & 0.000 & 0.400 & 661.000 & 1488 & 264.000 & 0.00 \\
\hline & 0.000 & 0.425 & 650.000 & 1463 & 276.000 & 0.00 \\
\hline & 0.000 & 0.450 & 640.000 & 1440 & 288.000 & 0.00 \\
\hline & 0.000 & 0.475 & 630.000 & 1417 & 299.000 & 0.00 \\
\hline & 0.000 & 0.500 & 620.000 & 1395 & 310.000 & 0.00 \\
\hline \multirow[t]{5}{*}{$1: 2.50$} & 0.000 & 0.400 & 625.000 & 1562 & 250.000 & 0.00 \\
\hline & 0.000 & 0.425 & 615.000 & 1538 & 261.000 & 0.00 \\
\hline & 0.000 & 0.450 & 606.000 & 1514 & 273.000 & 0.00 \\
\hline & 0.000 & 0.475 & 597.000 & 1492 & 283.000 & 0.00 \\
\hline & 0.000 & 0.500 & 588.000 & 1470 & 294.000 & 0.00 \\
\hline \multirow[t]{5}{*}{$1: 2.75$} & 0.000 & 0.400 & 592.000 & 1628 & 237.000 & 0.00 \\
\hline & 0.000 & 0.425 & 583.000 & 1604 & 248.000 & 0.00 \\
\hline & 0.000 & 0.450 & 575.000 & 1581 & 259.000 & 0.00 \\
\hline & 0.000 & 0.475 & 567.000 & 1559 & 269.000 & 0.00 \\
\hline & 0.000 & 0.500 & 559.000 & 1537 & 279.000 & 0.00 \\
\hline \multirow[t]{4}{*}{$1: 2.25$} & 1.850 & 0.350 & 684.000 & 1538 & 239.000 & 12.65 \\
\hline & 1.150 & 0.375 & 672.000 & 1513 & 252.000 & 7.73 \\
\hline & 1.250 & 0.400 & 661.000 & 1488 & 264.000 & 8.26 \\
\hline & 0.500 & 0.425 & 650.000 & 1463 & 276.000 & 3.25 \\
\hline \multirow[t]{4}{*}{$1: 2.50$} & 2.200 & 0.350 & 645.000 & 1612 & 226.000 & 14.19 \\
\hline & 1.850 & 0.375 & 635.000 & 1586 & 238.000 & 11.74 \\
\hline & 1.350 & 0.400 & 625.000 & 1562 & 250.000 & 8.43 \\
\hline & 1.250 & 0.425 & 615.000 & 1538 & 261.000 & 7.69 \\
\hline
\end{tabular}


All mortar mixes were proportioned using absolute volume method as prescribed in ACI Manual of Concrete Practice, Part 1 (American Concrete Institute, 1999).

Mixing of constituent material was performed in a epicyclical type mechanical mixer complying with specifications in ASTM C305-06 (1998c). Constituent materials of the mix were mixed as in accordance to mixing procedures and durations of mixing prescribed in ASTM C305-94 to produce mortars of plastic consistency.

Test methods: Rheological properties of the mortar mixes were investigated in term of mix slump determined in accordance to procedures prescribed in BS 1881-102:1983 (British Standards Institution, 1983a). Besides, flow test was performed in accordance to procedures in ASTM C230/C230M-08 (1998b) and ASTM C109/C109M-08 (1998a) to determine flow value of each mix in fresh state.

From each batch of mix, a total of 6 numbers of $100 \times 100 \times 100 \mathrm{~mm}$ cubes were fabricated according to BS 1881-108:1983 (British Standards Institution, 1983b). Mortar mix were cured in the mould for $24 \mathrm{~h}$ covered completely with polyethene sheeting prior to being remolded and cured in water tank at curing temperature of $20 \pm 2^{\circ} \mathrm{C}$ till age of test as recommended in BS 1881-111:1983 (British Standards Institution, 1983c). At the test age of 7 and 28days respectively, three cube specimens were taken out from the curing tank and dried to saturated surface dried condition. The specimens were then weighed in air and fully immersed in water using an electronic balance to the nearest $0.1 \mathrm{~g}$ for determination of their bulk density as per recommendations in BS 1881-114:1983 (British Standards Institution, 1983d).

Immediately after determination of bulk density, saturated surface dried specimens were then subjected to compression test as per procedures in BS 1881-114:1983 under continuous loading condition. Loading rate were maintained constant at $3 \mathrm{~mm} \mathrm{~min}^{-1}$ throughout the test and the cube specimens were loaded to failure.

\section{RESULTS AND DISCUSSION}

Fresh properties of mixes and super plasticizer dosage: Generally, it was observed that workability of mortar mixes with no super plasticizer content increases with increasing water/cement ratio. The observation is consistent with the fact that the water content of the mix is the main factor affecting workability of concrete whereby increase in water content will result in higher workability of mix (Neville, 1995). Mortar mixes with cement: Sand ratio of 1:2 exhibits highest level of workability in terms flow ability and slump of mix followed by mortar mix with cement: Sand ratio of 1:2.25 and 1:2.5 have similar level of flow ability for water/cement ratio range within 0.4-0.50. However, slump value of mortar mix with cement: Sand ratio of 1: 2.5 surpasses slump of mortar mix with cement: Sand ratio of $1: 2.25$ at water/cement ratio of 0.475 and 0.50 though both mixes exhibit similar slump value at lower water/cement ratio between 0.400 and 0.450 .

For mixes with batch number of 21-28, slump values of mixes were successfully maintained within the range of 50-90 $\mathrm{mm}$ as shown in Fig. 3 with the use of superplastcizer. Mortar mix with cement: Sand ratio of 1: 2.25 was observed to have lower required dosage of super plasticizer to achieve slump within the range of 50-90 mm in comparison with mortar mix with cement: Sand ratio of 1:2.5. This implies a higher economical use of super plasticizer with the use of mortar mix with cement: Sand ratio of 1: 2.25 as compared to 1: 2.5 mortar mixes to achieve a given level of workability.

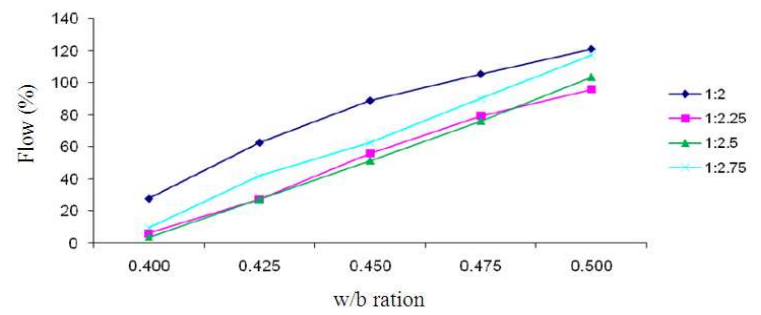

(a)

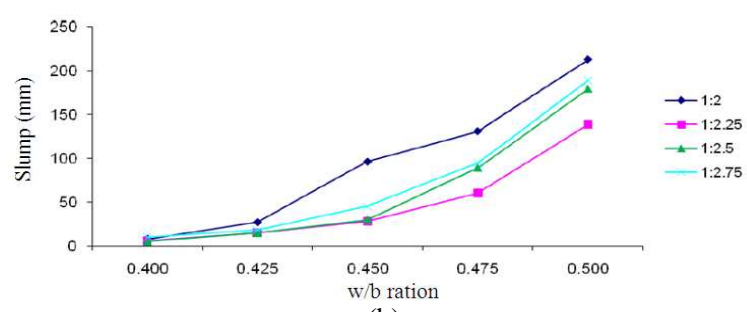

(b)

Fig. 2: Slump and flow of mortar mixes with various mix proportions

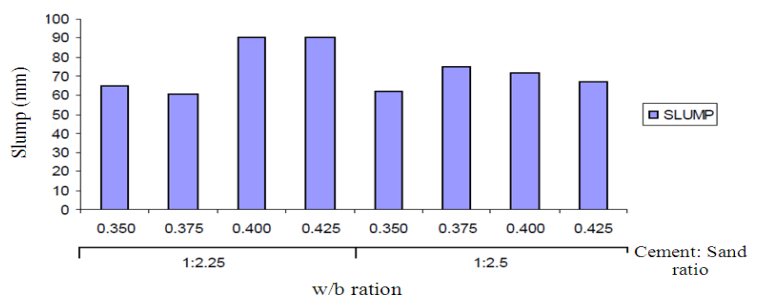

Fig. 3: Slump values of mixes with super plasticizer 
Am. J. Engg. \& Applied Sci., 3 (4): 643-649, 2010

Table 3: Fresh and hardened properties of mortar mixes

\begin{tabular}{|c|c|c|c|c|c|}
\hline Batch No. & Slump $(\mathrm{mm})$ & Flow diameter $(\mathrm{mm})$ & $\begin{array}{l}\text { Saturated surface dry } \\
\text { density }\left(\mathrm{kg} \mathrm{m}^{-3}\right)\end{array}$ & $\begin{array}{l}7 \text { days compressive } \\
\text { strength }(\mathrm{MPa})\end{array}$ & $\begin{array}{l}28 \text { days compressive } \\
\text { strength (MPa) }\end{array}$ \\
\hline 1 & 8 & 130.07 & 2228 & 41.82 & 47.87 \\
\hline 2 & 27 & 165.60 & 2209 & 35.38 & 47.53 \\
\hline 3 & 96 & 192.16 & 2184 & 30.33 & 43.70 \\
\hline 4 & 131 & 209.03 & 2177 & 24.58 & 39.80 \\
\hline 5 & 213 & 224.93 & 2177 & 23.38 & 38.17 \\
\hline 6 & 6 & 107.80 & 2233 & 47.85 & 54.04 \\
\hline 7 & 15 & 129.29 & 2226 & 43.21 & 51.89 \\
\hline 8 & 28 & 158.73 & 2214 & 41.96 & 47.92 \\
\hline 9 & 60 & 182.48 & 2196 & 36.88 & 44.61 \\
\hline 10 & 139 & 199.33 & 2183 & 32.21 & 39.78 \\
\hline 11 & 5 & 105.40 & 2246 & 47.66 & 52.93 \\
\hline 12 & 15 & 129.44 & 2240 & 42.73 & 51.27 \\
\hline 13 & 30 & 154.00 & 2219 & 38.78 & 46.61 \\
\hline 14 & 89 & 179.30 & 2217 & 33.00 & 43.73 \\
\hline 15 & 179 & 207.33 & 2216 & 31.82 & 39.71 \\
\hline 16 & 10 & 111.50 & 2275 & 45.83 & 51.75 \\
\hline 17 & 18 & 144.30 & 2264 & 42.12 & 51.03 \\
\hline 18 & 45 & 165.50 & 2251 & 34.26 & 44.57 \\
\hline 19 & 95 & 193.50 & 2243 & 26.40 & 41.84 \\
\hline 20 & 189 & 221.00 & 2233 & 25.81 & 39.75 \\
\hline 21 & 65 & 163.04 & 2234 & 48.95 & 56.53 \\
\hline 22 & 61 & 166.94 & 2235 & 43.10 & 48.94 \\
\hline 23 & 90 & 196.32 & 2238 & 39.31 & 48.04 \\
\hline 24 & 90 & 183.69 & 2201 & 35.83 & 44.75 \\
\hline 25 & 62 & 143.74 & 2232 & 47.00 & 54.88 \\
\hline 26 & 75 & 166.11 & 2217 & 37.96 & 52.35 \\
\hline 27 & 72 & 168.09 & 2201 & 34.05 & 49.70 \\
\hline 28 & 67 & 176.58 & 2202 & 32.85 & 46.77 \\
\hline
\end{tabular}

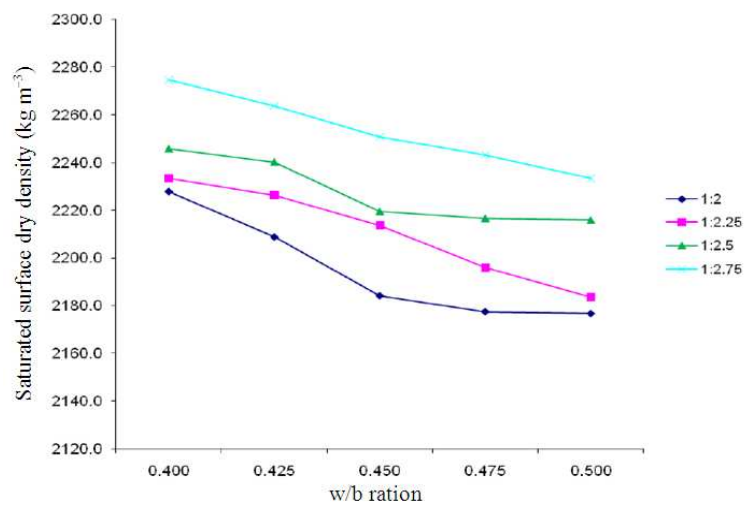

Fig. 4: Variation in saturated surface dry density with increasing $\mathrm{w} / \mathrm{b}$ ratio for mixes without super plasticizer

Saturated surface dry density: Saturated surface dry densities of each mortar mixes cast is shown in Table 3. As can be seen in Fig. 4, densities of mortar mix with any cement: Sand ratio reduces uniformly with increase in water/cement ratio. This behavior is largely due to higher degree of mix porosity with increasing amount of mixing water as evaporated free mixing water in concrete mix resulted in formation of pores within the cement paste matrix (Neville, 1995). It can also be observed that at any water/cement ratio, density of mix decreases with increasing cement content when cement: Sand ratio of mix varies from 1:2.75-1:2.00.

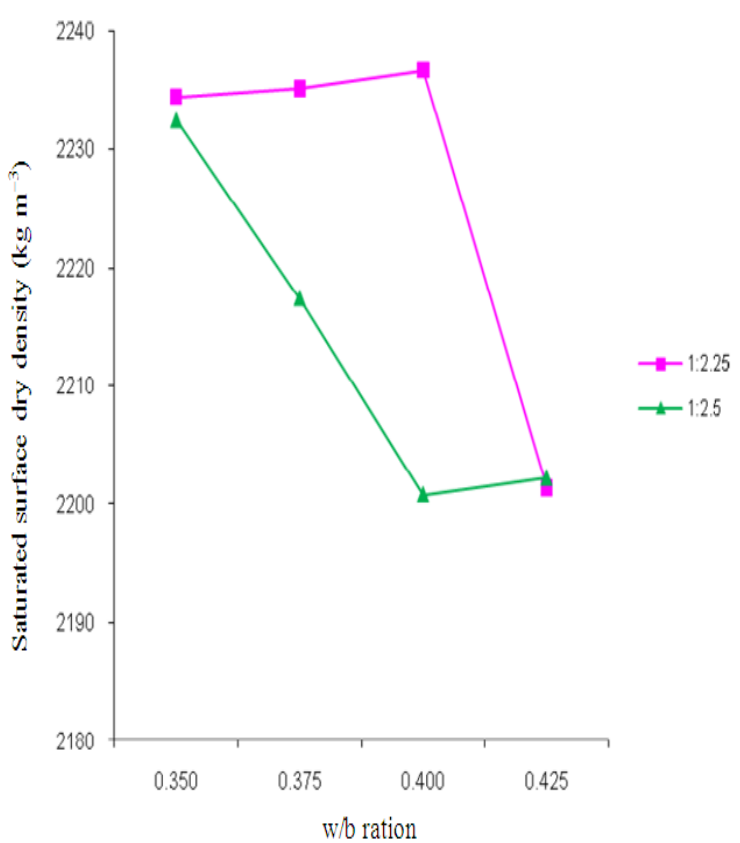

Fig. 5: Variation in saturated surface dry density with increasing $w / b$ ratio for mixes with super plasticizer

In the presence of super plasticizer, mortar mix with cement: Sand ratio of 1:2.25 exhibit increasing saturated surface dry density with increase in 
water/cement ratio up to 0.4 and dropped drastically when water binder ratio of mix reaches 0.425 as can be seen in Fig. 5. From Fig. 5, it can be seen that density of 1:2.25 mix is generally higher than 1:2.5 mix. This can be attributed to higher workability of 1:2.25 mix in comparison with 1:2.5 mix which enable better compaction and lower degree of porosity.

Compressive strength of mix: The compressive strength of mortar mixes at the age of 7 and 28 days is summarized in Table 3. For mortar mixes with no super plasticizer content, it can be observed that mortar mix with cement: Sand ratio of 1:2.25 exhibit highest compressive strength for all water/binder ratios at the age of 7 and 28 days as shown in Fig. $6 a$ and $b$.

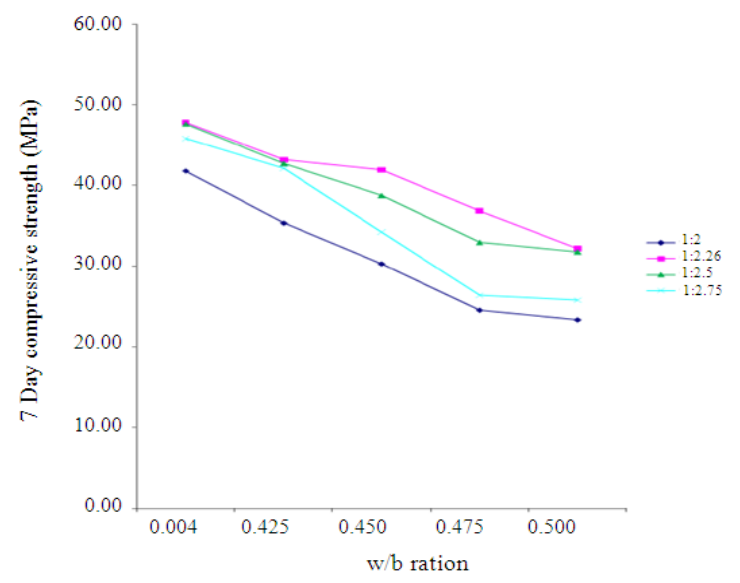

(a)

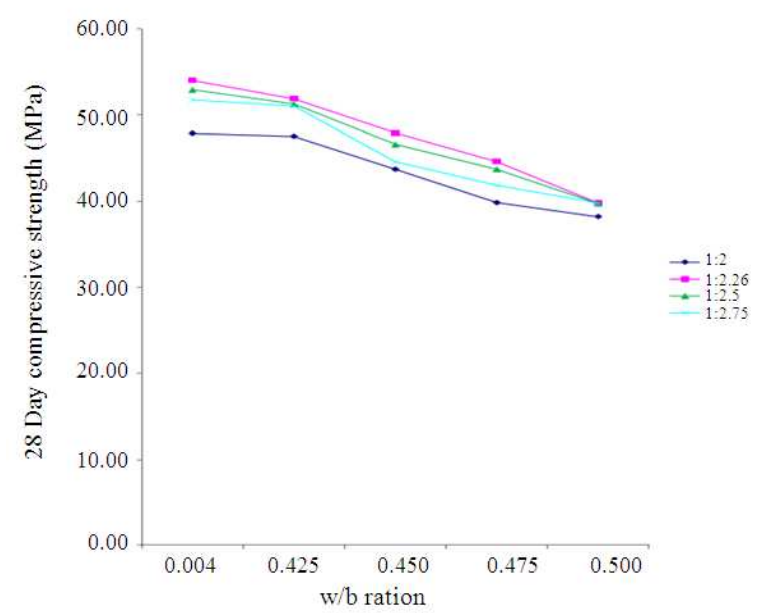

(b)

Fig. 6: Correlation between 7 day and 28 day compressive strength of mix with $\mathrm{w} / \mathrm{b}$ ratio
At a given water/cement ratio, when cement: sand ratio is varied from 1:2.00-1:2.75, compressive strength of mix at both 7 and 28 days age increases to a maximum value when cement sand ratio is $1: 2.25$ as can be observed graphically in Fig. 7a and b. In Fig. 7a, it can be noted that the compressive strength of mix with cement: Sand ratio of 1:2.25 was found to be significantly higher in comparison with mix with cement: Sand ratio of 1:2.0, 1:2.5 and 1:2.75 at the age of 7 days.

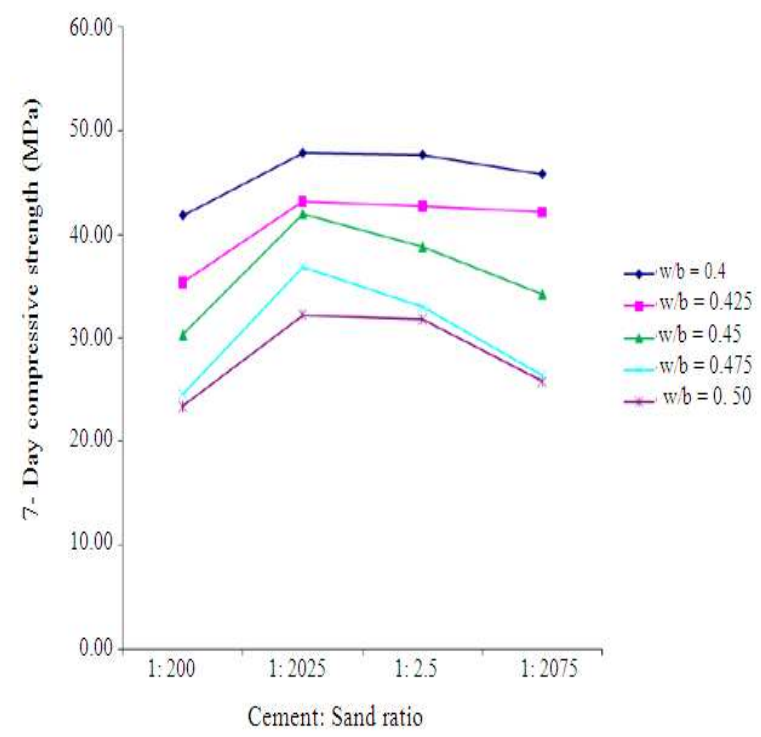

(a)

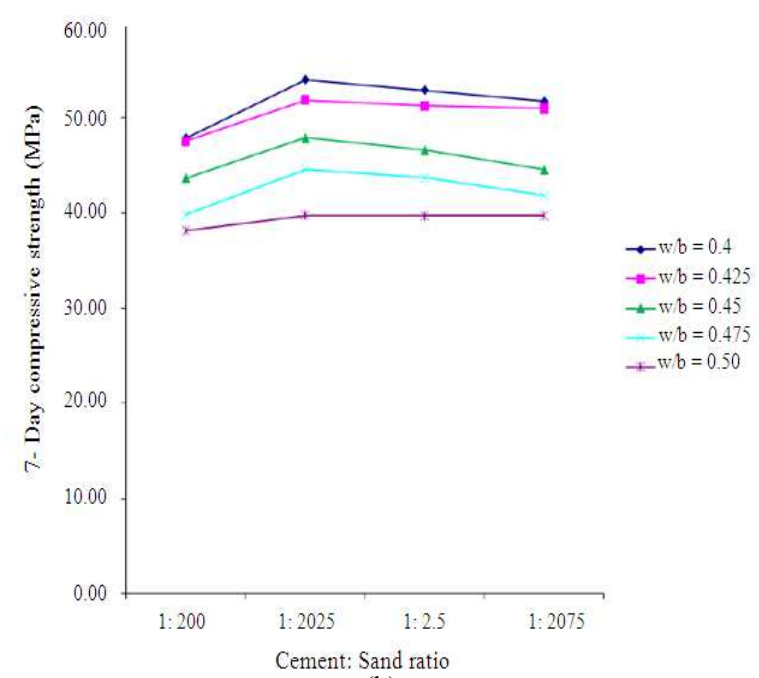

(b)

Fig. 7: Correlation between 7 day and 28 day compressive strength of mix with cement: Sand ratio 
Am. J. Engg. \& Applied Sci., 3 (4): 643-649, 2010

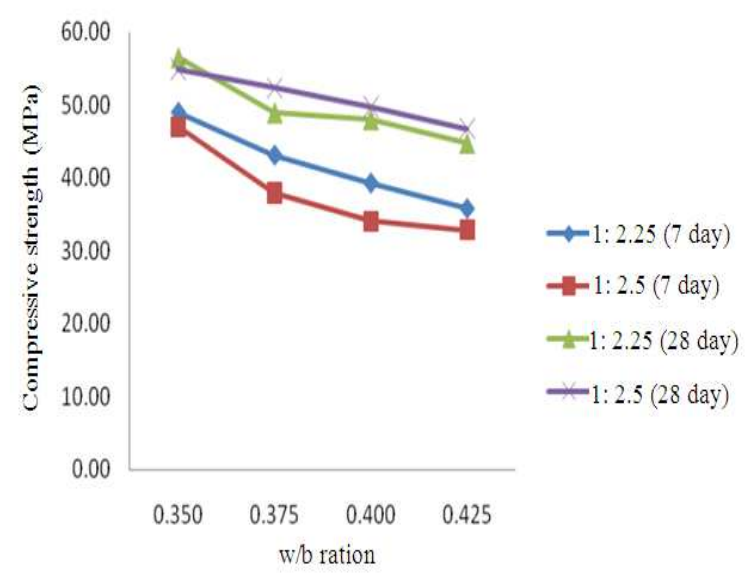

Fig. 8: Correlation between 7 and 28 days compressive strength with w/b ratio for mortar mix with super plasticizer

At the age of 28 days, though 1:2.25 mortar mix still exhibit the highest compressive strength for any water/cement ratio, the difference in compressive strength in comparison with other mixes has decreased as can be seen in Fig. 7b. Another important observation is that the cement rich mortar mixes with cement: Sand ratio of 1:2 consistently exhibit lowest compressive strength in comparison with other leaner mixes at both 7 and 28 days as can be seen in Fig. 6a and b.

Upon incorporation of super plasticizer in the mortar mix with cement: Sand ratio of 1:2.25 and 1:2.5, 7 days compressive strength of 1:2.25 mix was observed to be consistently higher in comparison with $1: 2.5 \mathrm{mix}$ for water/cement ratio between $0.35-0.425$ as shown in Fig. 8. However, at the age of 28 days, strength of mix with cement: Sand ratio of 1:2.5 surpasses that of 1:2.25 mix for water/binder ratio range between 0.3750.425 as can be seen in Fig. 8 .

By comparing strength of mortar mix with cement: Sand ratio of 1:2.25 and water binder ratio of 0.400 and 0.425 with and without super plasticizer content, it was observed that incorporation of super plasticizer in mortar mix resulted in reduction in 28 days compressive strength of hardened mortar mix as can be seen in Fig. 9a and b. The same trend can be seen for mixes with cement: Sand ratio of 1:2.5. The reduction in 28 days compressive strength due to incorporation of super plasticizer in mortar mix with cement: Sand ratio of 1:2.25 is more significant than mortar mix with cement: Sand ratio of 1:2.5 as shown in Fig. 10.

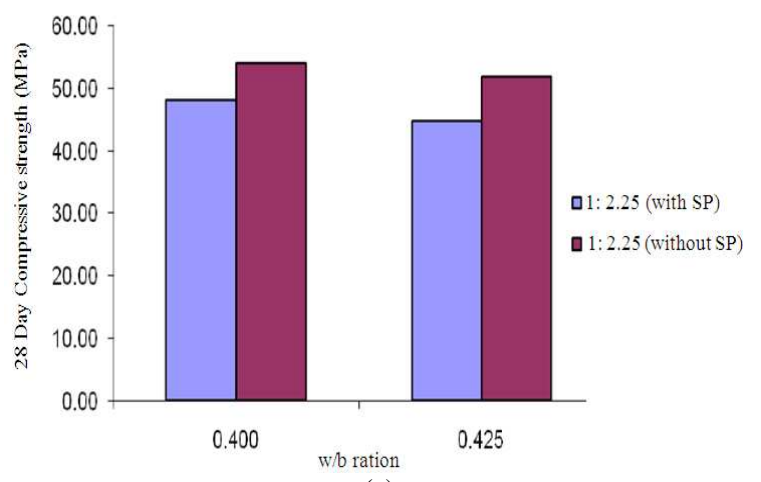

(a)

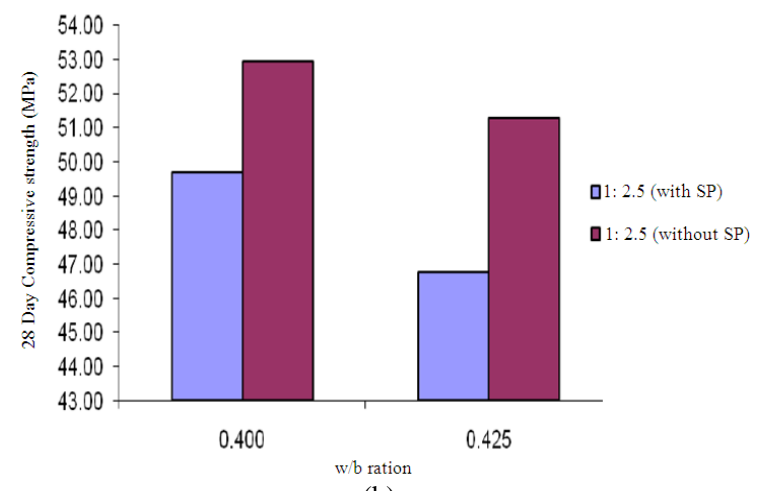

(b)

Fig. 9: Comparison between 28 days compressive strength of mortar mixes with and without SP

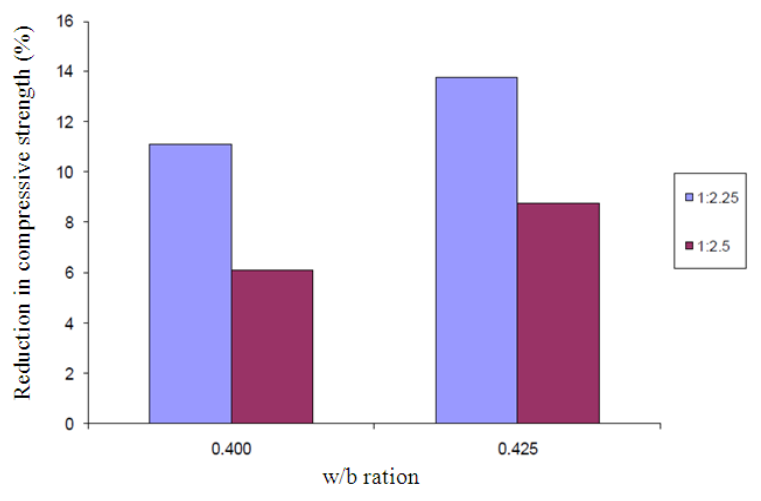

Fig. 10: Percentage reduction in compressive strength of hardened mortar mixes due to incorporation of super plasticizer

\section{CONCLUSION}

From experimental data acquired throughout the laboratory investigation done on mortar mixes with various mix proportions, the following conclusion can be derived: 
- Compressive strength of mortar mix does not vary linearly with increasing quantity of cement

- Optimum cement content is achieved at cement: sand ratio of 1:2.25 for water/cement ratio ranging between 0.40 and 0.50 to ensure maximum compressive strength of mortar mix produced

- Economical use of binder can be achieved with the use of mortar mix with cement: sand ratio of 1 : 2.25 as compared to conventional mortar mix (with cement: Sand ratio between 1:1.5 and 1:2) while maintaining optimum level of compressive strength

- Incorporation of super plasticizer in the mortar mix with cement: Sand ratio of 1:2.25 results in higher degree of enhancement in workability as compared to mortar mix with cement: Sand ratio of 1: 2.5

- Rate of early strength gain of mortar mix with cement: Sand ratio of 1:2.25 is significantly higher in comparison with 1:2.0, 1:2.5 and 1:2.75 mortar mixes

- Flow values of mortar mixes vary proportionately with their slump value

- Incorporation of super plasticizer in mortar mixes resulted in reduction of compressive strength of hardened mortar mix

\section{ACKNOWLEDGEMENT}

This research study was funded by the University Sains Malaysia Fellowship Programme and Research Grant of the second author.

\section{REFERENCES}

American Concrete Institute, 1999. ACI 211.1 standard practice for selecting proportions for normal, heavyweight and mass concrete. IHS. http://aec.ihs.com/document/abstract/LIJCFBAAA AAAAAAA

ASTM C109/C109M-08, 1998a. Standard test method for compressive strength of hydraulic cement mortars. ASTM.

http://www.astm.org/Standards/C109.htm

ASTM C230/C230M-08, 1998b. Standard specification for flow table for use in tests of hydraulic cement. ASTM. http://www.astm.org/Standards/C349.htm

ASTM C305-06, 1998c. Standard practice for mechanical mixing of hydraulic cement pastes and mortars of plastic consistency. ASTM. http://www.astm.org/Standards/C305.htm
British Standards Institution, 1983a. BS 1881-102: Testing concrete. Method for determination of slump. BSI. http://shop.bsigroup.com/en/ProductDetail/?pid=00 0000000000048831

British Standards Institution, 1983b. BS 1881-108: Testing concrete. Method of making test cubes from fresh concrete. BSI. http://www.techstreet.com/cgibin/detail?doc_no=BS\%7C1881_108_1983\&produ ct_id $=1100501$

British Standards Institution, 1983c. BS 188: Part 111: Testing concrete. Method of normal curing of test specimens $\left(20^{\circ} \mathrm{C}\right.$ method). BSI.

British Standards Institution, 1983d. BS 1881-114: Testing concrete. Method of determination of density of hardened concrete. BSI. http://www.techstreet.com/standards/BS/1881_114 _1983?product_id=1100507

British Standards Institution, 1990. BS 812-102: Testing aggregates. Method for sampling. BSI. http://shop.bsigroup.com/en/ProductDetail/?pid=00 0000000000207801

British Standards Institution, 1992. BS 882: Specification for aggregates from natural sources for concrete. BSI. http://www.techstreet.com/standards/BS/882_1992 ?product_id=1107511

British Standards Institution, 1997, BS 5328-1. Concrete. Guide to specifying concrete. BSI. http://www.techstreet.com/standards/BS/5328_1_1 997?product_id=1103558

British Standards Institution, 2000. Concrete-Part 1: Specification, performance, production and conformity. BSI. http://engineers.ihs.com/document/abstract/FFVPG BAAAAAAAAAA

Neville, A.M., 1995. Properties of Concrete. 4th Edn., Longman Publishing Group, USA., ISBN: 10: 0582230705, pp: 864.

Nedwell, P. and R.N. Swamy, 1994. Ferrocement: Proceedings of the Fifth International Symposium. 1st Edn., Spon Press, New York, ISBN: 10: 0419197001, pp: 508. 